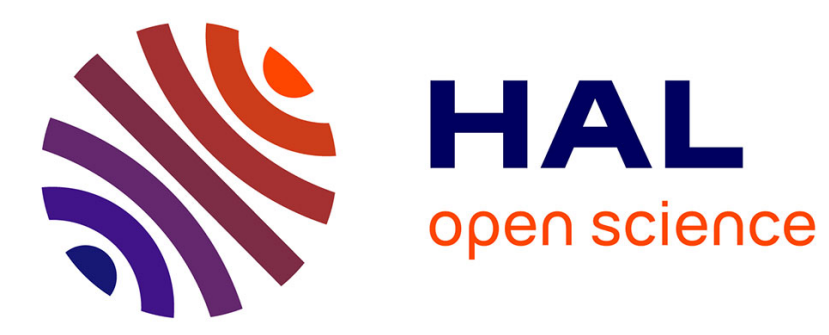

\title{
The Uses of the Term Hypothesis and the Inquiry Emphasis Conflation in Science Teacher Education
}

Jakob Gyllenpalm, Per-Olof Wickman

\section{To cite this version:}

Jakob Gyllenpalm, Per-Olof Wickman. The Uses of the Term Hypothesis and the Inquiry Emphasis Conflation in Science Teacher Education. International Journal of Science Education, 2011, pp.1. 10.1080/09500693.2010.538938 . hal-00676991

\section{HAL Id: hal-00676991 \\ https://hal.science/hal-00676991}

Submitted on 7 Mar 2012

HAL is a multi-disciplinary open access archive for the deposit and dissemination of scientific research documents, whether they are published or not. The documents may come from teaching and research institutions in France or abroad, or from public or private research centers.
L'archive ouverte pluridisciplinaire HAL, est destinée au dépôt et à la diffusion de documents scientifiques de niveau recherche, publiés ou non, émanant des établissements d'enseignement et de recherche français ou étrangers, des laboratoires publics ou privés. 


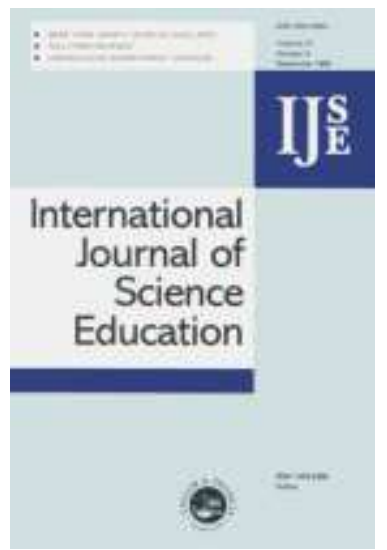

The Uses of the Term Hypothesis and the Inquiry Emphasis Conflation in Science Teacher Education

\begin{tabular}{|r|l|}
\hline Journal: & International Journal of Science Education \\
\hline Manuscript ID: & TSED-2010-0015.R3 \\
\hline Manuscript Type: & Research Paper \\
\hline Keywords : & teacher education, hypothesis, focus groups \\
\hline Keywords (user): & laboratory work, language, inquiry \\
\hline \multicolumn{2}{|l}{} \\
\hline
\end{tabular}

\section{SCHOLARONE ${ }^{m}$ Manuscripts}


Tabel 1. A summary of the different customs of using the term 'hypothesis' in four cultural institutions relevant for science teacher education.

\begin{tabular}{|l|l|}
\hline Cultural Institution & Customary use of 'hypothesis' \\
\hline 1. Scientific research & $\begin{array}{l}\text { 'Hypothesis' refers to a tentative explanation, from which } \\
\text { predictions can be derived, and that connects to a more } \\
\text { comprehensive theoretical framework. }\end{array}$ \\
\hline 2. Pure science courses & $\begin{array}{l}\text { The term 'hypothesis' is not commonly used or discussed } \\
\text { in laboratory tasks and inquiry oriented activities. }\end{array}$ \\
\hline $\begin{array}{l}\text { 3. Science education } \\
\text { courses for teachers }\end{array}$ & $\begin{array}{l}\text { 'Hypothesis' means a guess about an outcome, and is } \\
\text { frequently used (but not discussed explicitly) in laboratory } \\
\text { tasks and inquiry oriented activities. } \\
\text { 'Hypothesis' means a guess about an outcome, and is } \\
\text { frequently used (but not discussed explicitly) in laboratory } \\
\text { tasks and inquiry oriented activities. }\end{array}$ \\
\hline
\end{tabular}


1 The Uses of the Term Hypothesis and the Inquiry Emphasis Conflation in Science Teacher

2 Education

3

4

5

6

7

8

9

Abstract

This paper examines the use and role of the term 'hypothesis' in science teacher education as described by teacher students. Data was collected through focus group interviews conducted at seven occasions with 32 students from six well known Swedish universities. The theoretical framework is a sociocultural and pragmatist perspective on language and learning, introducing the notion of pivot terms to operationalise language use as a habit and mediated action. We describe three different customs of using the term 'hypothesis' within four cultural institutions that can be said to constitute science teacher education in Sweden. Students were found to habitually use the term hypothesis as meaning a guess about an outcome. This is contrasted to the function of this term in scientific research as a tentative explanation. We also found differences in how this term was used between the pure science courses given by the science departments of universities and science education courses taken only by teacher students. Findings also included further support for school students hypothesis fear reported in an earlier study. It is discussed how these findings can obstruct learning and teaching about the nature of scientific inquiry. Constructivist theories of learning are suggested as a possible origin of these problems. The findings are also related to curricular reform and development.

\section{Introduction}

In the current debate on curriculum development in science education, two notions stand out: scientific literacy and inquiry. Scientific literacy has been discussed in depth by Roberts (2007) who distinguishes between what he calls Visions I and II of curriculum aims in science education. Simply put, Vision I involves an emphasis on science as a body of knowledge in its 
own right, whereas Vision II puts an emphasis on science as a part of human culture and society at large. In either case, for someone to be scientifically literate, an understanding of scientific inquiry is fundamental. That is to say, an understanding of how scientific

knowledge about the world is generated through processes of scientific investigation.

However, despite many reform efforts teachers continue to be unclear about the meaning of inquiry in science education (Anderson, 2007; DeBoer, 1991). In part this may be due to the fact that the term inquiry is used to refer both to a pedagogical strategy for teaching science, not explicitly connected with a targeted knowledge in terms of learning about inquiry. This is

50 problematic, as it has been shown that an understanding of the nature of scientific inquiry is 
51 not gained merely by participating in inquiry activities, but that these issues must be

52 addressed and reflected upon explicitly (Lederman, 1999; Schwartz, Lederman, \& Crawford,

53 2004; Windschitl, Thompson, \& Braaten, 2008a). In analysing the tradition of laboratory

54 work in Swedish secondary schools, we found that teachers seemed to conflate methods of

55 teaching (i.e. inquiry as a pedagogical approach) and methods of scientific inquiry (i.e. the

56 targeted knowledge when learning about inquiry) (Gyllenpalm, Wickman, \& Holmgren,

57 2009). This included failing to distinguish between the concepts of hypothesis and prediction

58 and using hypotheses as pedagogical tools for teaching the results of science thus further

59 obscuring learning about scientific inquiry. In this article, we call this conflation of means

60 (methods of teaching) and ends (methods of scientific inquiry) in science teaching for the

61 inquiry emphasis conflation. The purpose of the study reported on in this article was to

62 investigate if the results from our previous study would be corroborated by interviews with

63 another group of informants (i.e. teacher students instead of experienced teachers). In addition

64 this different group of informants also allowed us to examining the role teacher education in

65 Sweden might have in reproducing the inquiry emphasis conflation.

66

67

68

69

70

\section{Theoretical Framework}

In this study we take a sociocultural and pragmatist perspective on language and learning. The focus of sociocultural theory is to explicate the relationship between social, historical and cultural contexts on the one hand, and individual action on the other (Wertsch, 1998). In the analysis presented here the particular cultural contexts are those of school, university education and scientific research, which we will refer to as cultural institutions (Rogoff, 1990; Säljö, 2005). Cultural institutions are relatively stable systems of human relations, communicative patterns, physical artefacts, activities, routines and other types of social arrangements on various levels of complexity that stabilize social interaction and that humans 
learn to relate to and act within (Säljö, 2005). They include both bureaucratic and material

dimensions as well as more informal systems of practice (Rogoff, 1990). Institutions are in this way systems of established and embedded social rules that structure social interactions, although the rules are not always explicit and compelling in a definite way (Hodgson, 2006).

The modifier 'cultural' refer to that these institutions also embody cultural values and purposes (Rogoff, 1990), and have been shaped by their particular historical and contingent developmental path (Wertsch, 1998).

The relationship between cultural institutions and individuals' actions within these can be approached by analysing mediated action and habits. Mediated action refers to an agent acting by means of, or mediated by, cultural artefacts (Wertsch, 1998), with the most ubiquitous cultural artefact being language (Säljö, 2005). Mediational means both provide affordances and constrains (Wertsch, 1998) for how we communicate, act and think. Our uses of language, including particular distinctions and divisions, is to a large extent habitual (Wickman, 2006). By habits we mean predispositions and tendencies for certain kinds of actions in certain situations (Dewey, 1930), and not strictly repetitive behaviour in a biological sense (Cohen, 2007). Institutions are upheld by the habits of individuals, simultaneously as institutions and the mediational means they provide, shape individuals habits (Dewey, 1930; Hodgson, 2007; Maréchal, 2010). We call these collectively shared habits, that characterise cultural institutions, customs (Dewey, 1930; Cohen, 2007). Being socially transmitted, habits require the attention and will of the agent while learning them, but once established they tend to function without explicit reflection. Nevertheless, habits can be made the object of explicit deliberation, which is a first step in changing habits, and the transformation of habits for coping with new situations can be conceptualised as learning (Rorty, 1979; Wickman, 2006). 
102 Four different cultural institutions have emerged as relevant in describing and analysing the 103 results presented here: $\underline{\text { scientific research, }}$ pure science courses, $\underline{\text { science education courses for }}$ 104 teachers and school science. These cultural institutions are interrelated but they can be briefly 105 described individually as follows. Scientific research refers to basic or applied research at a 106 university or the equivalent with the aim of increased or better knowledge of natural processes 107 and phenomena. Pure science courses refer to courses given by a science department at a 108 university, often led by an active researcher, and with no particular orientation towards

109 teacher education. This type of course tends to focus quite exclusively on introducing students 110 to a well-established body of scientific knowledge. Science education courses for teachers, on 111 the other hand, are given by the teacher education department or the equivalent, and are often 112 led by teachers with a lot of experience from teaching science in schools. This type of course 113 often has the dual purpose of teaching students science and simultaneously teaching them

114 how to teach science in schools (sometimes called 'parallel processes'), although the 115 emphasis between these two purposes may vary. School science is here science as a school 116 subject in secondary and upper secondary schools.

118 Language use and the meaning of words

119 A pragmatist perspective on language means that instead of seeing language as an outer 120 expression or representation of an inner mental state, as is usually the case in cognitive 121 perspectives, the meaning of words or any utterances are to be found in their use and 122 consequences (James 1907/1995; Wickman, 2006; Wickman \& Östman, 2002). This means 123 that words do not have an essential or universal meaning but must be understood as part of an 124 activity, context, or what Wittgenstein called a 'language-game' (Wickman, 2006). To 125 understand a word is at the same time to know how to play the language-game it is a part of. 
126 Also, language can, to a large extent, be understood as functioning through habits and

127 customs. In language-games the use, and thus meaning, of words are usually not questioned

128 but are typically understood as part of a practice as a whole (Hardwick, 1971). The fact that

129 most utterances 'stand fast', i.e. are not question by the individuals participating in an activity,

130 is a necessary condition for communication (Wickman \& Östman, 2002; Wittgenstein, 1968).

131 This means that to learn a language-game is not simply to know the use of certain words but

132 also means the acquisition of habits of using these words as part of an activity (Wickman,

133 2004). In order to reflect upon the customs (i.e. shared habits) of the major cultural institution

134 relevant to science teacher education, it is therefore relevant to study and make explicit the

135 particular uses of language that are associated with them.

136 We define a pivot term as a single word or term that can be used to highlight how two

137 or more different cultural institutions and their associated language-games overlap or

138 intersect. It can metaphorically be described as a term on which one can balance two such

139 systems - a common point around which they can be said to revolve. A pivot term thus relates

140 to some central aspect of two or more activities, or language-games, with distinctively

141 different purposes, resulting in the word having radically different meanings and connotations

142 in these activities. If the customs of using a particular term differs significantly between two

143 cultural institutions it may be described as a pivot term. The same pivot term may thus

144 mediate quite different action in different activities. Pivot terms are special compared to other

145 words, only because they can be positioned to provide a point of leverage for analytically

146 separating two or more activities. This is not an essential or universal quality of a certain class

147 of words, but a description of a role or function that a term may play when comparing its

148 customary use in relation to the different purposes of different cultural institutions. Analysing

149 the use of potential pivot terms is thus a way to operationalise how specific words can play a

150 central role in mediating action. 
152 The Use of 'Hypothesis' in Scientific Research

153 The possible pivot term analyzed in this paper is 'hypothesis' and its use in the cultures that

154 meet in science teacher education. In the results section we present empirical data on its use in

155 the cultures that teacher students are directly involved in. However, to examine how these

156 uses are related to the aim of teaching teacher students about inquiry as it is carried out in

157 scientific research, a comparison needs to be made with its use in scientific research.

158

159 The word 'hypothesis' is commonly used in science to refer to a tentative explanation related

160 to some observed phenomena (Chalmers, 1999). A hypothesis is not a single prediction

161 (McComas, 1998) but a suggestion about how the data is connected (Wilson, 1990). Often, it

162 is a proposition about a correlation or causal mechanism. What follows are three examples of

163 hypotheses from recent scientific research. All examples are taken from articles published in

$164 \quad$ Nature in the year 2000 (Hansson, 2006).

165 1. Neurotransmitter receptors of type D5 differ from those of type D1 in having special

166 functional interactions with $G A B G_{A}$ receptors.

167 2.Certain gravel depositions in Hawaiian coastal slopes were created in a single event by giant 168 tsunamis.

169 3. Super conductivity will arise in $C_{60}$ at high temperatures if it is hole-doped.

170 These hypotheses all have in common that they in different ways state tentative explanations,

171 with reference to causal or functional relationships, of natural phenomena. Example one

172 proposes as "functional interaction", example two how a geological feature was "created" (i.e.

173 caused) and example three proposes "hole-doping" as a factor that might cause the

174 phenomenon of "super conductivity" under certain conditions. Furthermore, they all refer to

175 theoretical concepts (e.g. superconductivity, neurotransmitter, gravel deposit) that have 
176 meaning only in relation to a more comprehensive theory and research programme of some

177 kind. Example three may superficially be mistaken for a prediction. If one only considers

178 grammatical form, this may be true, in a sense, but the key here is the second part, 'if it is

179 hole-doped'. This refers to a cause or explanation of the predicted superconductivity in this

180 particular case. For this explanation to make sense, the hypothesis must be connected to a

181 more comprehensive model relating the particulars of $C_{60}$ within the even more

182 comprehensive theory of solid state physics. This implies that a hypothesis cannot stand

183 alone, and that the theory or research objective to which it is related is needed to separate a

184 scientific hypothesis from a groundless guess about an outcome or arbitrary fortune-telling

185 (McComas, 1998).

186 It can be questioned whether hypotheses play an important role in all forms of scientific

187 research (Hansson, 2006). However, it is definitely widely used in the way described here in

188 science studies, which is the field of scholarship in which the nature of scientific inquiry

189 (NOI) is systematically studied and described.

190

191 Research Question

192 The objective of this article is to examine the uses of the potential pivot term 'hypothesis' and

193 analyse the possible consequences of these for science teacher education. In particular the

194 research questions are:

195 1. How do science teacher students use the word 'hypothesis' and describe its function when

196 discussing examples of laboratory tasks in their own university education?

197 2. In what ways are the customary ways of using the word 'hypothesis' different in the

198 cultural institutions that constitute science teacher education in Sweden? 
199 The first research question is addressed by presenting and analysing transcripts from the focus 200 group interviews, while the second question is addressed analytically based on the findings 201 related to question one.

Method

204 In order to obtain information about the characteristic customs of teacher education in a 205 manner that was not too artificial, and simultaneously hear a large number of informants from 206 a range of backgrounds, focus group interviews were chosen as the method of data collection.

207 This approach was inspired by Volante and Earl (2002), who used focus groups to explore 208 teacher students understanding of the conceptual orientations of their own teacher education 209 programmes and practicum experiences, and also Hurtado, Carera, Lin, Arellano, and 210 Espinosa (2009), who used focus groups to study university students experiences with the 211 culture of science.

\section{Sample Selection}

214 Six well-known universities were chosen to obtain a broad representation of teacher education

215 programmes in Sweden. The target group was teacher students who specialised in natural

216 science for secondary schools and who were approaching the end of their education. In all

217 seven focus group interviews were conducted with a total of 32 students and 3 to 6

218 participants in each group at the following universities: Gothenburg University, Malmö

219 University, Mälardalen University, Stockholm University, Umeå University and Uppsala

220 University

221 Focus Group Interviews

222 The focus group interviews were orchestrated to situate the conversations in a context similar 223 to the type of conversations that teacher educators may have with their students. This was 
224 done by asking students to bring concrete examples of laboratory work from their own

225 university education and discuss these in terms of educational purposes. The interviews lasted

226 on average 1.5 hours and were conducted by the first author, according to the following

227 structure:

228 1. Introduction and presentations

229 2. Focusing exercise: ranking the purposes of laboratory tasks

2303 . Students tell about their own examples of laboratory work

231 4. 'Pedagogical methods and theories' are compared with 'Natural scientific methods and 232 theories'

233 At the beginning of the interview, the researcher repeated the information that the students 234 had been given before the meeting and described the overall objective and how data was 235 going to be used. During the interviews, an interview guide was used (Appendix A) to help 236 call attention to and focus on relevant themes of discussion.

237 A focusing exercise is described by Bloor, Frankland, Thomas, and Robson (2001) as 238 'an attempt to concentrate the group's attention and interaction on a particular topic' (p.43). In 239 our case, this was done by asking the students to agree upon a ranking of seven statements 240 about the main purposes of laboratory work in their university education, as perceived by 241 them (Appendix B). The statements were inspired by Roberts's seven curriculum emphases in 242 science education (Roberts, 1982). During the exercise, the students were asked to explain 243 their reasoning as they worked on the task and to refer back to concrete examples from their 244 own education. The exercise took approximately 30 minutes to complete.

245 After the focusing exercise, each of the examples provided by each student was 246 discussed. These mainly consisted of laboratory reports or instructions. The students were 247 asked individually to elaborate on the context in which the example was situated in their 248 education, and to relate it to the list of purposes discussed during the focusing exercise. As a 
249 final topic for the interview, two sheets of papers were distributed with two different topics or 250 themes (Appendix C) and the students were asked to discuss these in relation to the focusing 251 exercise and their own examples.

252 The objective of these preparations and tasks was to create conditions favourable for 253 engaging conversations, which we hoped would provide many natural opportunities to 254 elaborate on the meaning and use of inquiry related terms such as 'hypothesis'. It was not our 255 intention to elicit the students' views on the nature of the purpose of laboratory work or how 256 'pedagogical theories' might differ from 'natural scientific theories'. These themes were 257 instead used as heuristics to help create meaningful, content rich and focused conversations. 258 We feel that over all we succeeded with this and several students commented after the 259 interviews that they had found the event both inspiring and educative.

261 Analysis of Data

262 All focus group interviews were transcribed verbatim and then proofread to ensure a high 263 quality of the transcribed record. The transcripts were then coded in terms of the general 264 topics of the interviews as well as sections relating to the use of the term 'hypothesis'. This 265 provided an overview of the material. In the next step, the transcripts were re-coded in more 266 detail, with a focus on the use and mentioning of the term 'hypothesis' using the Transana 267 software for qualitative data analysis. All episodes containing references to hypotheses were 268 printed and sorted in subcategories in order to find the common themes described in this 269 article. The most representing transcripts have been chosen to be presented and commented 270 upon in the Result section. The transcripts are translations from verbatim Swedish transcripts 271 to English. Great care has been taken to stay as close as possible to original sense of the 272 wording, but the transcripts in Swedish also contain many grammatically odd formulations as 273 transcribed talk often does. 
274

275

276

277

278

279

280

281

282

283

284

285

286

287

288

289

290

291

292

293

294

295

296

\section{Results}

Here we present data from the focus group interviews to highlight the significant themes that emerged from the analysis of the use the pivot term 'hypothesis'. All of the names of the students are pseudonyms, and the names of the universities are anonymous, but consistently denoted by letters.

\section{The Dominant Use of "Hypothesis" in Teacher Education}

Although the word 'hypothesis' was used in different ways by the teacher students in this study, the use completely dominated the interviews was to equate a hypothesis with a proposition about 'what you believe will happen' when performing a laboratory task, i.e. a guess about an outcome. This is in line with how teachers were found to use this word in a previous study (Gyllenpalm et al., 2009), and also in line with how the use of this word in school science has been described elsewhere (Baxter \& Kurtz, 2001). Other uses such as equating a hypothesis with a research question, an assumption that can be tested and as a tentative explanation, were mentioned at a few rare occasions, but cannot be considered to be representative of the prevailing custom. Below is an example of this seemingly natural and spontaneous meaning given to the term by most students:

1. Sara: Hypothesis? Hypothesis is what you believe is going to happen in the experiment.

2. Klara: Yes.

3. Sara: That's what you're supposed to come up with before if it is a hypothesis... (University D) 
297 Students using the word 'hypothesis' as a guess about an outcome were also asked if they had 298 noted the fact that this equates a hypothesis with a prediction. This was clearly not something 299 the students had considered, as exemplified in the following quote:

300 4. Interviewer: It sounds somewhat like a prediction as well.

301 5. Johan: Yes, well, yes perhaps you could better say that's what it is. It is nothing...

302 6. Interviewer: Is this something that you have distinguished between or talked about?

303 7. Several: No

304 8. Johan: You know it's not directly, it's not like we have formulated our own hypothesis 305 to be able to see if there is any difference, it's more like we have... I guess our, our 306 hypothesis was to be formulated, what do you think is going to happen with the one 307 that's in darkness and the one that is in light, and what does it depend on? So I guess 308 that's what we have written.

$309 \quad$ (University C, Group 2)

310 The last comment by Johan refers to a take-home laboratory task in which the students

311 were to perform an experiment to test how two different treatments (one environment

312 with sunlight and one without) affected the growth of a plant. This was part of a science

313 education course for teachers. As exemplified here, the use of a hypothesis as a guess

314 about an outcome dominated the focus group conversations. There were no indications

315 of the students having noted that this use conflates a hypothesis with a prediction.

\section{Absence of Hypotheses in Pure science courses}

318 The custom of having students formulate their own hypotheses as guesses about the outcome

319 of a laboratory task in school science is in stark contrast to the customs of the pure science 320 courses. In these courses, talk about hypotheses is rare and it is normally not an important 321 concept in laboratory tasks. 
10. Jan: We haven't had a lab like that.

11. Petra: We haven't had a lab like that, no.

\section{(University E)}

Whereas it can easily be seen in the complete interview transcripts that the two above quotes explicitly refer to pure science courses, it is inferred from the context in the next two quotes. As this distinction was found to be important only after analysing the interviews, it was not addressed explicitly during the interviews.

12. Klara: Yeah, but it's just that you rarely get to, I mean there are no hypotheses in that way; instead you often get to do lab tasks in which you know what will happen if you mess up, sort of. There is a correct result in some way. And that ... Yes ... then there isn't really a hypothesis and then you don't work with hypotheses in that way. (University $F$ )

These quotes illustrate that in the pure science courses, there is little use for or even mentioning of hypotheses. Previous research has also shown that in pure science courses, laboratory tasks are usually highly structured and recipe like (Hult, 2000). The absence of hypotheses in laboratory tasks in pure science courses is also accompanied by what seems to be a rather low emphasis on discussion about the nature of science and the nature of scientific inquiry in general. In the quote below, Klara is referring to item number seven in the focusing exercise when she concludes that they have not discussed the nature of scientific inquiry:

14. Mattias: It's what they say...

15. Klara: It's what they always talk about, but no one wants to define.

16. Sara: Nobody wants to explain it, no. 
17. Klara: And it's really important that we know.

(five turns further down)

18. Klara: And in that case, if number seven has to do with that, I definitely think that we don't get into that when we do laboratory tasks and experiments at all.

19. Camilla: No

\section{(University D)}

Although hypotheses are rare in pure science courses, there were examples discussed during the interviews that can be said to involve hypothesis testing more explicitly. Again, it is not always clear if the distinction between pure science courses and science education courses for teachers can be applied in all of these examples. In any case, they constituted rare and more comprehensive tasks in which the students were given more freedom and responsibility to conduct their own inquiry projects.

20. Lalla: The only lab task, or whatever you should call it, it was this scientific article. Because what we, in my group did, was that we were to look at, there are aquatic woodlice of different colours, they are grey, brown, green, and then we had a hypothesis that it depends on where they grow, where they live. Depending on if they live off the green seaweed they become green, and if they live on the brown seaweed, they become brown. It was the only time that we formulated a hypothesis, and so to say tested if that was the case. But that is probably the only time I have done anything like that.

(University B)

This example was recalled by Lalla as the interviewer continued to probe the role played by the notion of a hypothesis in their education. We can see that Lalla is talking about a hypothesis in the form of a tentative explanation; however, it should be noted that this did not seem to be a more reflective or systematic use of this term, as will become clearer in the next 
372 section. As she says, this constitutes an unusual or unique example, in that it was the only

373 time they were supposed to formulate their own hypothesis and design corresponding

374 investigations to test it.

\section{Science education courses for teachers}

377 The absence of emphasis on and discussion of hypotheses in laboratory tasks in pure science 378 courses is contrasted by science education courses for teachers. Below, Jonas explicitly states 379 that he only recalls talk of hypotheses in this type of course. In the following examples, it can

380 be deduced from the larger context of the interview conversations that the students are 381 referring to the same kind of courses.

382 21. Interviewer: So in your laboratory tasks, this stuff about reasoning around a hypothesis doesn't seem to have been a big thing.

22. Jonas: I guess it's really only existed during the didactics [science education courses for teachers] lab tasks. (University A)

The science education courses for teachers seem to have two features that are particularly relevant for the present discussion. The first is the so-called 'parallel process' already mentioned. The second is that talk about hypotheses was often mixed with talk about theories of learning. In the next quote, we see how a student reasoned about the purpose for using hypotheses in schools as a pedagogical tool:

23. Interviewer: So have you talked a lot about hypotheses and what function they have?

24. Carola: Yes, and that is something we use during our practicum as well and that we are to use later in the teacher profession in which when you do lab work with the students, it is often the method you use. That the students should get to try but also perhaps have some, yes, a conception, what will happen and then you find out and it is 
397

398

399

400

401

402 To Carola, a hypothesis seems to be associated with a pedagogical method. The

403 pedagogical function of the hypothesis in the teaching method she is describing is to

404 elicit the students' preconceptions, a notion usually connected to conceptual change

405

406

407

408

409

410

411

412

413

414

415

416

417

418

419

420

421

like a way for the students, for them to discover what is, what science consists of. What is it really? And you want to, yes, in a way you want to encourage the students to learn more, and so on, and not serve everything on a plate. Or what do you guys feel?

(University C, Group 1)

theories of learning (Park, 2006). Here we note that "method" is also a potential pivot

term related to 'hypothesis'. In the context of science education this term is often

ambiguous as can bee seen in the definition of the inquiry emphasis conflation. Below is

a further illustration of referring to hypotheses as a pedagogical tool:

25. Miriam: The hypotheses were very important in the air lab.

26. Interviewer: Ok, in what way, what did it mean?

27. Miriam: Well, it was important in some way that we had a conception before we did the actual eh experiment how... a conception about what could happen, and then we were supposed to confirm or deny if it was true by performing the experiment.

28. Lisa: But Maria, surely it was a part of these lab tasks, wasn't it that students' conceptions was that in this case, that it contains nothing, it is empty [...]?

29. Miriam: Yes, that's right because precisely this about dropping your own hypothesis, that it is like wrong, so it is pretty difficult to do because you prefer that your everyday conceptions perhaps are the ones that are true, so to speak, it is difficult to drop it because then you lose in a way a part of your sense of reality in some way. And then it's important to understand the new context how it works, how the theory perhaps really is. So this was actually a part of the thing with this really. 
423 It seems as if it is only in this context of a pedagogical approach to teaching the products of 424 science that the notion of a hypothesis is common and has a clearly justified role for these 425 students. Miriam's last comment also demonstrates the personal nature of a hypothesis when 426 used as a pedagogical tool, when she refers to 'dropping your own hypothesis' (turn 29), a 427 point that will be discussed later.

\section{Reproducing the Customs of School Science}

430 Discussion about hypotheses does not seem to be very common in most pure science courses 431 at the university level, and in particular, not in connection with laboratory work. The 432 exception is science education courses for teachers, as noted, although in these, talk about 433 hypotheses also seems to be taken for granted and not reflected upon critically. In the 434 following quote by Albert, it is not completely clear if he is referring to a pure science course 435 or to both kinds of courses. Nevertheless, the quote illustrates his perceived gap between the 436 customs at the university and those in school; it also corroborates the earlier findings that the 437 hypothesis is a guess about an outcome in the school custom (Gyllenpalm et al., 2009).

438 30. Albert: I can refer back to my practicum school once again speaking about hypothesis. 439 In part, I agree about what has been said because when I hear the word hypothesis, I 440 think about my [practicum] school when they write lab reports and regardless if you 441 talk about year seven or year nine, they always get to start by writing their own 442 hypothesis. How they think, what they believe... They read through the actual lab task 443 and find out about what we are going to do a lab about. And the lab question is, what 444 result they are to find out. Then they always get to write down what they believe is 445 going to happen. And hypothesis in that sense, I can't recall from the university 
[courses], that now you are going to do this laboratory task and you are going to find out about this and this, and what do you think will happen?

(University B)

Albert describes the recurring habit of 'always beginning with writing a hypothesis' as a guess about an outcome, and he contrasts this with the courses he has taken at the university of which he 'can't recall' anything similar. Later in the same interview, Lina refers back to Albert's statement:

31. Interviewer: So hypothesis as "what you think will happen", do you think that it is a good definition of what a hypothesis is?

32. Lina: Perhaps not scientifically like, but I can follow Albert's track that it is like that I interpret the word sort of. That is also how I have asked students to formulate hypotheses before you have done laboratory tasks. And then like, well, what is a hypothesis? And then I've probably explained it sort of with the words that it's like what you believe is going to happen, what colour you think it will be or what you believe, like that.

(University B)

Lina's statement shows a certain questioning of the meaning of a hypothesis that can be connected to the interviewer encouraging the students to think about hypotheses in a scientific context. However, what she describes is how she normally has used the word during her practicum. These examples provide a snapshot of how the existing customs in school science continues to be reproduced.

Questioning the Use of a Hypothesis as a Guess about an Outcome 
469 On some occasions, the conversations led to the students questioning the role of a hypotheses 470 in scientific research compared to the more familiar school science and their own teacher 471 education.

33. Mattias: Yes, but if you now think that in real research where they really come up with 473 new things, do they really have hypotheses there in the same way we have them now? That they sit down and think for an hour first, hmm...what's going to happen?

475 ( a few lines further down)

476 34. Tomas: [...] I mean we never start with that, with the idea, instead we start with the complete experiment. And that can never science, I mean research could never start with an experiment and then try to find out why you have this experiment, it seems a bit twisted.

\section{(University D)}

481 Mattias raises a doubt as the interviewer asks if they all agree with the just stated definition of 482 a hypothesis as a guess about an outcome. A few lines further down, Tomas develops this 483 thread of reasoning by stating that it is a paradox to be given a method in the form of a recipe 484 to follow in a laboratory task and then being asked to guess what will happen. A similar 485 argument was provided by Johan in another interview in which he questioned the use of the 486 notion of a hypothesis and linked this to thoughts about studying causality.

487 35. Johan: If you look at, if you think about, eh, I don't know if it says, I think it says that 488 we are to write a hypothesis, and when you think about it, it's not really a hypothesis 489 in the same sense that it is when you write or do something more scientific, but it's 490 more that we do an assessment, what we believe is going to happen. It's not directly... 491 36. Interviewer: What would be more scientific?

492 37. Johan: I feel like you perhaps should, more like draw up a, a theory for what you 493 believe could, eh, effect. I believe this is going to happen because, and that because of 
494

495

496

497

498

499

500

501

502

503

504

505

506

507

508

509

510

511

512

513

514

515

516

517

this, we want to do this experiment. But here we have been assigned to do this experiment and guess what we think is going to happen. So it is a bit more like guessing...

(University C, Group 2)

Johan's reasoning made Alexandra, who was in the same group, uncertain. She seemed to have been certain that a hypothesis simply meant a guess about an outcome. This lead to a meaning exchange between Johan and Alexandra in which Johan developed his argument about the role of hypotheses in a similar way to that of Tomas above. What both Johan and

Tomas are observing is that there is a strange kind of reversed epistemology when it comes to the prevailing use of a hypothesis as a guess about an outcome. What this means is that the students are presented with a situation or experimental procedure (a scientific method) and then asked about what they believe will happen. At the same time, everyone involved knows that there is a single answer that is already known that is accepted as the correct one, i.e. there is a didactical contract (Brousseau, 1997). Later in the same interview we note that, although the familiar custom is challenged, they continue to show a kind of loyalty to the customs of school science.

38. Alexandra: Ok, but it doesn't feel like you very often in that case, that you formulate any hypothesis when you work, I mean like we have done.

39. Johan: No, not with them.

40. Staffan: And that the students, no that's true, in school so...

41. Alexandra: But you still call it a hypothesis.

42. Staffan: Yes, well, I guess it is this form so that it's like and in that way, you prepare yourself for the way it will be like perhaps in high school.

43. Johan: Yes. 
44. Interviewer: Is this something that you have discussed with your teachers or earlier in connection to laboratory tasks?

45. Several: No.

46. Staffan: In any case, very little, but not that I can remember.

47. Alexandra: No.

\section{(University C, Group 2)}

524 Alexandra is given an eye-opener and brings to light the existing contrast between the 525 meaning of a hypothesis in school science compared to scientific research. Simultaneously, it 526 seems as if the school custom exerts a strong pressure on the students, and that they tend to 527 reproduce this custom as Staffan's statement in turn 42 indicates.

Hypothesis Fear

530 In the existing school custom in which a hypothesis usually means a guess about an outcome,

531 there is also a certain emphasis on the 'you' part of this statement, i.e. what you (the student)

532 personally believe. What this suggests is that 'you' are identified with 'your hypothesis' as if 533 'you are your hypothesis'. This is in line with the teachers' pedagogical use of the concept as 534 a tool for making students aware of their own preconceptions or misconceptions (Gyllenpalm 535 et al., 2009). Disregarding for a moment that this use of the notion gives a distorted image of 536 the nature of scientific inquiry, there is also reason to suspect that the identity between 'you

537 and your hypothesis' is the root of the hypothesis fear that both teachers and teacher students 538 have reported observing in school children (Gyllenpalm et al., 2010). Lina's statement from 539 turn 32 is continued, and it demonstrates this point, which is also corroborated by the rest of 540 the group. 
48. Lina: But, eh, at least the students I have had have had a really difficult time to formulate, they have been very uncertain when they try to formulate hypotheses, thinking that it's a bit scary like when they don't really know if it really is correct...

49. Olle: Students I've had have seen it more like a competition that "I have to be right". Because it has often happened then that they have written it down afterwards, if they are very competitive. "Yes, I don't write it yet, but look to see what happens first and then write it with a big exclamation mark, that yes, I made the correct guess, I was right!"

50. Lina: Yes (laughter)

51. Albert: I also recognize this, that there is a kind of uncertainty, that they are afraid of writing something incorrect. I have tried to explain to them that you can never lose credit based on the hypothesis.

(University B)

A strong emphasis on teaching students the correct explanations (Roberts, 1982) and the fact that because of this, the main purpose of performing laboratory tasks is to reach the correct conclusion (Andrée, 2007) most likely contribute to this hypothesis fear. The hypothesis becomes a tool for psychological manipulation and blackmailing and the stress caused is likely to contribute to students developing a negative attitude towards science as a school subject. Blackmailing occurs if students feel a need to play along with the 'guess the answer' game, because they want to please the teacher or achieve a certain grade even though they are uncomfortable. Simultaneously, there seems to be a reaction in some schools against the prevailing custom of using a hypothesis as a guess about an outcome because of the conflict it easily provokes.

52. Klara: We have never really discussed hypotheses either like in any context the way I see it, because when I was doing my practicum, it's like a lot of teachers are totally 
against using hypotheses. So I feel very ambivalent and we have never had any discussion about this.

53. Melanie: Are they against it?

54. Klara: It can get very, in some classes, it can get very confusing when they write hypotheses, as the teachers see it. Because then they make up really strange things and then they can even imagine that "we wrote it in our hypothesis so it must be true" so it can get a bit weird like that.

(University D)

574 Like many others, Klara notes that the subject of hypotheses is not a theme that has been

575 discussed during laboratory work or at any other time. The counter reaction to the stress

576 caused by the reversed epistemology apparently expressed by some teachers is

577 understandable. However, the reaction is misdirected, since it is based on taking the existing

578 custom as a given and then simply rejecting it as wrong. This is like throwing out the baby

579 with the bathwater. The teachers are then 'completely against using hypotheses' perhaps

580 without realizing that what they call a hypothesis may be something quite different from what

581 it normally means in scientific research.

582

583

Discussion

$584 \quad$ Summary of Results

585 The research objective of this article was to describe how teacher students use the potential

586 pivot term 'hypothesis' and how this use relates to a number of cultural institutions that can

587 be said to constitute science teacher education. We found that the students habitually used

588 'hypothesis' as equivalent to a guess about an outcome, in line with the customs of school

589 science (Gyllenpalm et al., 2009). Although some students began to question this during the

590 course of the interviews, there was also evidence of the tendency to remain loyal to the 
591 custom of school science. The use and function of hypotheses at university courses, as

592 described by the students, inspired us to distinguish between pure science courses and science

593 education courses for teachers. In the pure science courses, little or no emphasis is placed on

594 hypotheses or hypothesis testing as a part of laboratory tasks. Only in some rare cases when

595 students get to do more comprehensive inquiry projects did the concept of a hypothesis

596 appear, but this seems to be a one-time event for most students. This is a finding in line with

597 previous research on science teacher education in Sweden (Lager-Nyqvist, 2003). Thus, it

598 seems as if the students are expected to invent or discover the logic and subtleties of

599 formulating hypotheses and hypothesis testing on their own during the course of completing

600 one single more comprehensive inquiry project. It is a big leap for most students to make, and

601 as research shows, they are unlikely to learn much more about the nature of scientific inquiry

602 just from participating in this type of project without explicitly reflecting upon it from a

603 philosophy of science perspective (Lederman, 1999; Windschitl, 2003).

604 In contrast to the pure science courses, talk about hypothesis seems frequent in science

605 education courses for teachers, and it is often associated with a pedagogical methodology and

606 theoretising about the nature of how individuals learn scientific concepts. Although

607 hypotheses were a common part of these courses, it was not a topic that had been discussed

608 often. In fact, there was nothing to suggest that it had been discussed in terms of scientific

609 research methodology. Finally, we also noted that the students confirmed our earlier finding

610 that school students may feel anxiety over formulating their own hypotheses as guesses about

611 an outcome; a phenomenon we have labelled 'hypothesis fear' (Gyllenpalm et al., 2010). Not

612 all themes were discussed in depth at each interview, although most themes were at least

613 touched on in all groups. Summarising the results, it is a surprisingly homogenous choir

614 formed by students from all over the country. 
615 The uses of the term 'hypothesis' in the different contexts, or cultural institutions,

616 described and analysed here are summarised in Table 1 below. These cultural institutions can

617 be conceptualised a being connected in chain of partly overlapping cultures in the order given

618 by the numbers in Table 1. Our results illustrate, by focusing on the pivot term "hypothesis", 619 a specific way in which the continuity of this chain between the cultures of scientific research 620 on and school science is broken. This break problematic since an important objective of 621 school science is to introduce learners to the culture, practices and language-games of 622 scientific research (Rogoff, 1990; Wickman, 2006). However, describing concrete and 623 specific aspects of this break, as we have tried to, also suggests ways of overcoming these 624 problems. Furthermore, three questions are raised by the results presented here. First, what is 625 the origin of these radically different uses of 'hypothesis' in contexts where they might be 626 expected to coincide? Second, how are the different customs that differentiate these cultures 627 reproduced in respect to the use of 'hypothesis"? And, third, what are the consequences of this 628 state of affairs for teaching and curriculum development? Our answers to these questions are 629 speculative and draw on the educational research literature, as well as on our results and 630 theoretical framework.

$631 \quad$ [Insert Tabel 1 here]

632 Constructivism as a Possible Origin of the Inquiry Emphasis Conflation

633 There is reason to believe that failing to distinguish between a hypothesis and a 634 prediction in school science is connected with the influences of constructivist theories of 635 learning. Constructivist theories of learning can be traced to Piaget's theory of individual 636 development of cognitive schemata through a process of accommodation resulting from a loss 637 of mental equilibrium (Piaget, 1964/2003). Piaget's theory and the early elaborations of it to 638 suit the field of science education research tend to mix theories of how individuals learn on a 639 short time scale, and theories of how science as a collective enterprise advances over the 
640 course of hundreds of years (Carey, 1999; Driver \& Easley, 1978; Posner, Strike, Hewson, \&

641 Gertzog, 1982). Park (2006, p. 488) recently summarised teaching based on constructivism as

642 being composed of four stages: 'recognition of prior idea, cognitive conflict, resolution of

643 conflict, and recognition of the modified idea.' Somewhere along the way, the notion of

644 hypothesis seems to have been hijacked as a tool for eliciting students' prior ideas and setting

645 the stage for a cognitive conflict to occur. In this process, the hypothesis was confused with a

646 prediction, and since the objective has not traditionally been to teach students about NOI, this

647 collapsed distinction did not appear to have any negative consequences. However, if an

648 understanding of NOI is important, this conflation becomes problematic. Furthermore, we

649 note that due to the existing, but tacit, didactical contract (Brousseau, 1997) that characterises

650 school science, this pedagogical use of the hypothesis seems to lead to the reported hypothesis

651 fear suffered by students. The didactical contract generally states that what is important to

652 learn are the correct explanations and producing the correct results in a laboratory task. As

653 these explanations and results are known, there is no incentive for students to take a guess that

654 turns out to be wrong because of the risk of appearing stupid. This risk and the prospect of

655 wasted intellectual effort combined with a desire to please the teacher can be hypothesised to

656 produce the anxiety reported amongst students.

657 It is possible that there are other origins of this conflation. One is that scientists

658 themselves, and college textbooks, may not always use these terms in a consequent manner

659 (Lawson, 2007). However, our results are in line with other critiques of constructivism that

660 address its epistemological and ontological basis (Kruckenberg, 2006; Säljö, 2000), and the

661 pedagogical practices derived from it (Caravita \& Halldén, 1994; Furtak, 2006). Also, the

662 idea that students misconception always obstruct learning and that teachers therefore need to

663 focus primarily on conceptual change has recently been criticised (Hamza \& Wickman,

664 2007). 
666 Reproducing the Inquiry Emphasis Conflation

667 Pure science courses generally omit discussions about hypotheses and the nature of

668 scientific inquiry (NOI). Laboratory tasks in these types of courses are usually closed, fully

669 structured and used to motivate, exemplify and teach the established theories and explanations

670 of science (Hult, 2000). However, it is not merely what is said and done that is important in

671 education, but also what is not said, what Östman (1998) called 'companion meanings'. Thus,

672 the pure science courses indirectly teach that talk about hypotheses in relation to research

673 methodology and NOI is not important enough to merit systematic teaching and assessment.

674 The fact that there is a general silence about NOI in general and the use of hypotheses in

675 particular in pure science courses could be an effective buffer between the education cultures

676 and the culture of scientific research, thus breaking the continuity of the chain. The link

677 between scientific research and the rest of the educational system is broken by the silence

678 about these issues; consequently, the pure science courses contribute to maintaining the status 679 quo.

680 The science education courses for teachers seem to import the school customs right into 681 the university. Here laboratory work is used both to illustrate science topics and teaching 682 methods simultaneously (the so-called 'parallel processes'), thus contributing more directly to 683 reproducing the inquiry emphasis conflation. In these courses, talk of hypotheses is common, 684 but also taken for granted and not reflected upon explicitly. It is also used as a pedagogical 685 tool rather than as a concept for research methodology. The hypothesis is connected to 686 theories of learning and methods for teaching, but not to discussions about and learning about 687 NOI. Thus, methods of teaching are not separated from methods of scientific inquiry, and the 688 inquiry emphasis conflation is perpetuated. In both the pure science courses and the science 689 education courses for teachers, we note that what we find here is probably not intended by the 
690 teachers leading these courses. It may be that they are aware of the distinctions we make here;

691 however, the point is that this is not what we find when talking to the teacher students. Hence,

692 if these issues have been raised, they have not had much impact.

693 Lortie (1975) has pointed out that teachers tend to teach the way they were taught, since 694 an average student has 'spent 13000 hours in direct contact with classroom teachers by the 695 time he [sic] graduates from high school' (p. 61), implying a powerful socialisation. As 696 described in the theoretical framework, cultural institutions are upheld by and simultaneously 697 shape individuals habits (Dewey 1930; Cohen 2007; Hodgson 2007; Maréchal 2010). Here 698 we have presented evidence demonstrating how the custom of using the term 'hypothesis' 699 indeed seems to be reproduced in school science with little or no influence from the customs 700 of scientific research passing through the filter of teacher education.

701

702

Implications for Teaching and Curriculum Development

703 Customs and other stable social structures are necessary for the growth and continuity 704 of cultural institutions. Understanding the characteristic customs of the cultural institutions 705 relevant for science education is a prerequisite for successful development and reform 706 projects (Dewey, 1930; Keys \& Bryan, 2001; Rowell \& Ebbers, 2004; Windschitl, 707 Thompson, \& Braaten, 2008b). Otherwise, projects may be hindered by participants acting 708 according to contradictory yet unexamined customs and habits related to key issues 709 (Fredrichsen, Munford, \& Orgill, 2006; Trumbull et al., 2005). Due to the status of 710 'hypothesis' as a potential pivot term, new curricular material that focus on hypothesis testing 711 as a dimension of learning about scientific inquiry may be interpreted within the school 712 custom of using hypotheses as a pedagogical tool. The concept of 'pivot term' may thus be 713 used to draw attention to this and other potential sources of confusion and miscommunication. 
In conclusion, this study both corroborates our earlier finding that there is a custom in

715

716

717

718

719

720

721

722

723

724

725

726

727

728

729

730

731

732

733

734

735

736

737

738

science education to conflate methods of teaching with methods of scientific inquiry

(Gyllenpalm et al., 2009, 2010), and, furthermore, describes how this conflations is related to

the different uses of the pivot term "hypothesis" in different cultural institutions relevant for

teacher education. The consequences of this conflation may be the reported hypothesis fear as

well as an increased difficulty in reaching the intended goals of scientific literacy because

NOI as a learning goal becomes difficult to distinguish and emphasise. Teacher educators

need to be aware of how the existing customs relate to the goal of learning about scientific

inquiry associated with scientific literacy. In pure science courses, we suggest that more effort be devoted to teaching about NOI and, in particular, the logic of hypothesis testing. In science education courses for teachers, work needs to be done to distinguish explicitly between theories of how individuals learn and descriptions of how knowledge production occurs in science at large. We also suggest that the personalized form of address should be abandoned when asking students for predictions and a hypothesis. Rather, there should be a critical examination of all possible explanations (hypotheses) and how they relate to the empirical evidence (predictions and actual outcomes).

\section{References}

Anderson, R. D. (2007). Inquiry as an Organizing Theme for Science Curricula. In S. K. Abell \& N. G. Lederman (Eds.), Handbook of research on science education (pp. 807830). London: Routledge.

Andrée, M. (2007). Den levda läroplanen. En studie av naturorienterande undervisningspraktiker i grundskolan. Stockholm: Stockholm Institute of Education.

Baxter, L. M., \& Kurtz, M. J. (2001). When a hypothesis is not an educated guess. Science and Children, 38, 18-20. 
739 Beveridge, W. I. B. (1961). The art of scientific investigation (Rev. ed.). London: Mercury.

740 Bloor, M., Frankland, J., Thomas, M., \& Robson, K. (2001). Focus Groups in Social $741 \quad$ Research. London: SAGE.

742 Brousseau, G. (1997). Theory of Didactical Situations in Mathematics. Dordrecht: Kluwer $743 \quad$ Academic Publishers.

744 Bybee, R. (2000). Teaching science as inquiry. In J. Minstrell, \& Emily H. van Zee (Eds.), 745 Inquiring into Inquiry Learning and Teaching in Science. Washington, DC: AAAS. 746 Caravita, S., \& Halldén, O. (1994). Re-framing the problem of conceptual change. Learning 747 and Instruction, 4, 89-111.

748 Carey, S. (1999). Sources of Conceptual Change. In E. K. Scholnick (Ed.), Conceptual 749 development: Piaget's legacy (pp. 293-326). Mahwah, N.J.: Lawrence Erlbaum. 750 Chalmers, A. F. (1999). What is this thing called science? (3rd ed.). Buckingham: Open $751 \quad$ University Press.

752 Cherryholmes, C. H. (1999). Reading Pragmatism. New York: Teachers College Press.

753 Cohen, M. D. (2007). Reading Dewey: Reflection on the Study of Routine. Organization $754 \quad$ Studies, 28(5), 773-786.

755 DeBoer, G. E. (1991). A history of ideas in science education: Implications for practice. $756 \quad$ New York: Teachers College Press.

757 Dewey, J. (1910). How we think. London: Heath \& Co.

758 Dewey, J. (1916/2004). Democracy and education. Mineola, N.Y.: Dover Publications.

759 Dewey, J. (1930). Human nature and conduct: An introduction to social psychology. New $760 \quad$ York: Modern Library.

761 Driver, R., \& Easley, J. (1978). Pupils and Paradigms: A Review of Literature Related to 762 Concept Development in Adolescent Science Students. Studies in Science Education, $763 \quad 5,61-84$ 
764 Fredrichsen, P. M., Munford, D., \& Orgill, M. (2006). Brokering at the Boundary: A 765 Prospective Science Teacher Engages Students in Inquiry. Science Education, 90, $766 \quad 522-543$.

767 Furtak, E. M. (2006). The problem with answers: An exploration of guided scientific inquiry 768 teaching. Science Education, 90(3), 453-467.

769 Gyllenpalm, J., Wickman, P.-O., \& Holmgren, S.-O. (2010). Secondary science teachers’ 770 771 Gyllenpalm, J., Wickman, P.-O., \& Holmgren, S.-O. (2010). Teachers' Language on Scientific 772 773 
788 Keys, C. W., \& Bryan, L. A. (2001). Co-Constructing Inquiry-Based Science with Teachers: 789 Essential Research for Lasting Reform. Journal of Research in Science Teaching, 38, $790 \quad 631-645$

791 Kruckenberg, R. (2006). A Deweyan Perspective on Science Education: Constructivism, 792 Experience, and Why We Learn Science. Science \& Education, 15, 1-30.

793 Lager-Nyqvist, L. (2003). Att göra det man kan: en longitudinell studie av hur sju 794 lärarstudenter utvecklar sin undervisning och formar sin lärarroll i naturvetenskap. 795 Göteborg: Acta Universitatis Gothoburgensis.

796 Lawson, A. E., Oertman, M., \& Jensen, J. (2007). Connecting science and mathematics: The 797 nature of scientific and statistical hypothesis testing. International Journal of Science 798 and Mathematics Education, 6, 405-416.

799 Lederman, N. (2004). Syntax of nature of science within inquiry and science instruction. In N. 800 Lederman (Ed.), Scientific Inquiry and the Nature of Science (pp. 301-317). London: $801 \quad$ Kluwer Academic Publishers.

802 Lederman, N., G. (1999). Teachers' understanding of the nature of science and classroom 803 practice: Factors that facilitate or impede the relationship. Journal of Research in $804 \quad$ Science Teaching, 36, 916-929.

805 Lortie, D. C. (1975). Schoolteacher: A sociological study. Chicago: University of Chicago $806 \quad$ Press.

807 Maréchal, K. (2010). Not irrational but habitual: The importance of 'behavioural lock-in' in $808 \quad$ energy consumption. Ecological Economics, 69, 1104-1114.

809 McComas, W. F. (1998). The principal elements of the nature of science: dispelling the 810 myths. In W. F. McComas (Ed.), The Nature of Science in Science Education 811 Rationales and Strategies (pp. 53-70). Dordrecht, The Netherlands: Kluwer Academic $812 \quad$ Press. 
813 Metz, K. (2004). The Knowledge Building Enterprises in Science and Elementary Science

814 Classrooms. In N. Lederman (Ed.), Scientific Inquiry and the Nature of Science (pp. 815 105-130). London: Kluwer Academic Publishers.

816 Östman, L. (1998). How companion meanings are expressed by science education discourse. 817 In D. A. Roberts \& L. Östman (Eds.), Problems of Meaning in Science Curriculum 818 (pp. 54-77). New York: Teacher College Press.

819 Park, J. (2006). Modelling Analysis of Students' Processes of Generating Scientific 820 Explanatory Hypothesis. International Journal of Science Education, 28, 469-489.

821 Piaget, J. (1964/2003). Cognitive Development in Children: Piaget, Development and 822 Learning. Journal of Research in Science Teaching, 40, 8-18 .

823 Posner, J. G., Strike, A. K., Hewson, W. P., \& Gertzog, A. W. (1982). Accommodation of a 824 Scientific Concept: Toward a Theory of Conceptual Change. Science Education, 66, 825 211-227.

826 Roberts, D. A. (1982). Developing the concept of curricular emphases in science education. 827 Science Education, 14, 10-25.

828 Roberts, D. A. (2007). Scientific Literacy/Science Literacy. In S. K. Abell \& N. G. Lederman 829 (Eds.), Handbook of research on science education (pp. 729-780). London: Lawrence 830 Erlbaum Associates Inc.

831 Rocard, M. (2007). Science education now: A renewed pedagogy for the future of Europe. 832 Luxembourg: Office for Official Publications of the European Communities. 833 Rowell, P., \& Ebbers, M. (2004). Shaping school science: Competing discourses in an 834 inquiry-based elementary program. International Journal of Science Education, 26, $835915-934$.

836 Rogoff, B. (1990). Apprenticeship in thinking: cognitive development in social context. 837 Oxford: Oxford University Press. 
838 Rorty, R. (1979). Philosophy and the mirror of nature. Princeton: Princeton University Press.

839 Rudolph, J., L. (2002). Portraying Epistemology: School Science in Historical Context.

$840 \quad$ Science Education, 87, 64-79.

841 Säljö, R. (2005). Lärande och kulturella redskap : om lärprocesser och det kollektiva minnet.

$842 \quad$ Stockholm: Norstedts akademiska förlag.

843 Schwab, J. J. (1962). The Teaching of Science as Enquiry. Cambridge: Harvard University

$844 \quad$ Press.

845 Schwartz, R. S., Lederman, N. G., \& Crawford, B. A. (2004). Developing views of nature of

846 science in an authentic context: An explicit approach to bridging the gap between

847 nature of science and scientific inquiry. Science Education, 88, 610-645.

848 Wertsch, J. V. (1998). Mind as action. Oxford: Oxford University Press.

849 Wickman, P.-O. (2004). The practical epistemologies of the classroom: A study of laboratory $850 \quad$ work. Science Education, 88(3), 325-344.

851 Wickman, P.-O. (2006). Aesthetic experience in science education: Learning and meaning852 making as situated talk and action. Mahwah, N.J.: Lawrence Erlbaum Associates.

853 Wickman, P.-O., \& Östman, L. (2002). Learning as discourse change: A sociocultural 854 mechanism. Science Education, 86(5), 601-623.

855 Windschitl, M. (2003). Inquiry projects in science teacher education: What can investigative 856 experiences reveal about teacher thinking and eventual classroom practice? Science $857 \quad$ Education, 87, 112-143.

858 Windschitl, M. (2004). Folk Theories of 'Inquiry': How Preservice Teachers Reproduce the 859 Discourse and Practices of an Atheoretical Scientific Method. Journal of Research in $860 \quad$ Science Teaching, 41(5), 481-512. 
861 Windschitl, M., Thompson, J., \& Braaten, M. (2008a). Beyond the Scientific Method: Model862 Based Inquiry as a New Paradigm of Preference for School science Investigations. Science Education, 92, 941-967.

864 Windschitl, M., Thompson, J., \& Braaten, M. (2008b). How Novice Science Teachers 865 Appropriate Epistemic Discourses Around Model-Based Inquiry for Use in 866 Classrooms. Cognition and Instruction, 26, 310-378.

867 Wilson, E. B., Jr. (1990). An introduction to scientific research. New York: Dover 868 Publications.

Wittgenstein, L. (1968). Philosophical investigations. (3rd ed.). Oxford: Blackwell.

870

Volante, L., \& Earl, L. (2002). Teacher Candidates' Perceptions of Conceptual Orientations in 871 Their Preservice Program. Canadian Journal of Education, 27(4), 419-438.

872

873 Appendix A

874 Interview Template

875 1. Can you describe the example you have chosen? (Context? Prerequisite knowledge? Time 876 frames? Research question? How was the question answered? Group or individual? Aids?

877 Assessment? Presentation of results? Comparisons of results?)

878 2. How did you understand the purpose of this as part of your own teacher education?

879 3. Particular words/notions to try to focus on:

$880 \quad-\quad$ Question, guess, hypothesis

$881 \quad-\quad$ Method, observation, experiment, scientific, systematic, objective

$882 \quad-\quad$ Prior knowledge, theory, model

883 - Logical reasoning, critical thinking, proof, cause, prediction

884 - Presentation, report, examine, compare with the results of others

885 4. Other questions that may be relevant to ask: 


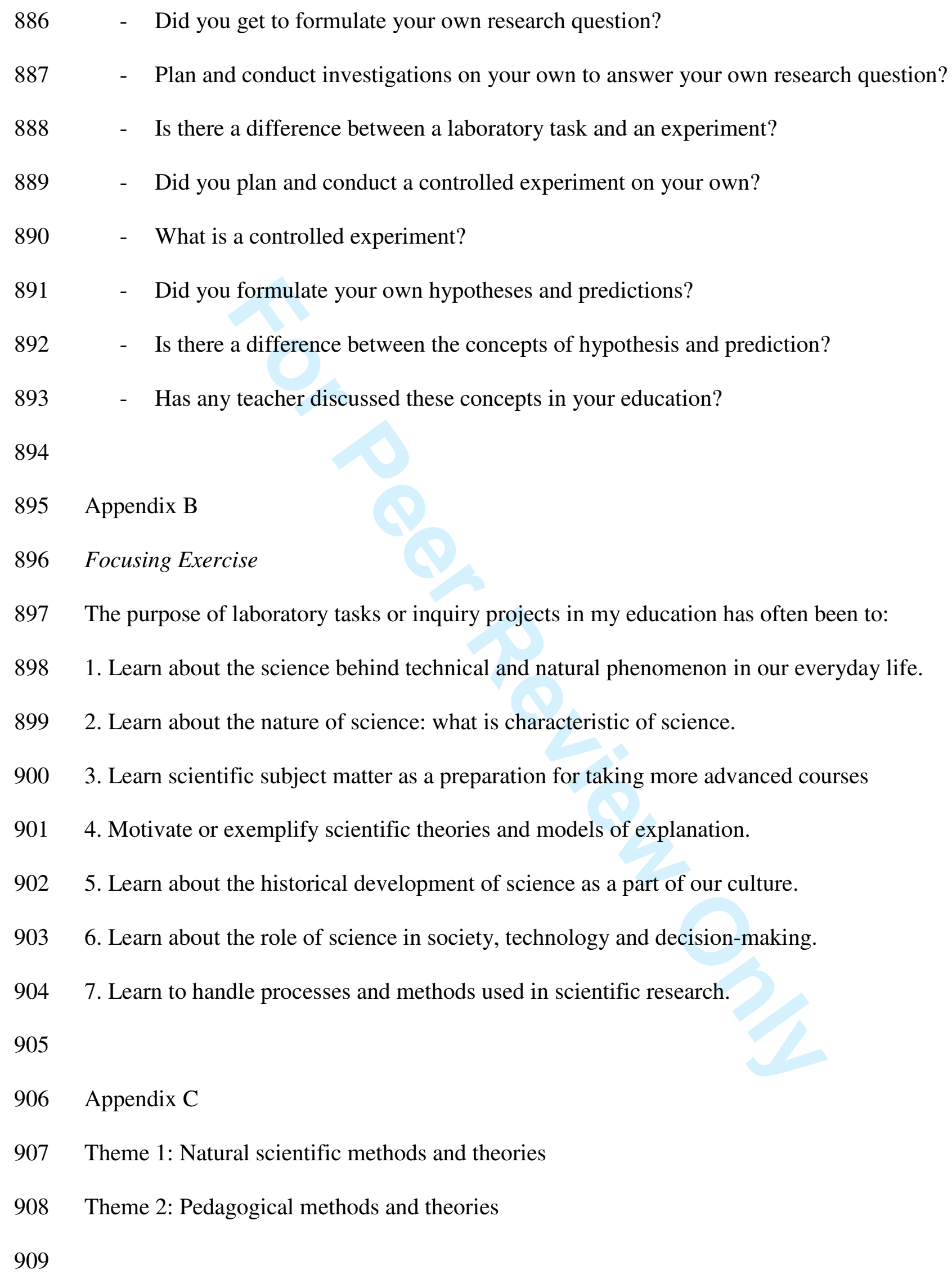

